\title{
Research on effectiveness of coal mine safety supervision system reform on three types of collieries in China
}

\author{
Quanlong Liu • Xinchun Li • Fuyuan Guan
}

Received: 30 December 2013/Revised: 6 August 2014/Accepted: 10 August 2014/Published online: 31 October 2014

(C) The Author(s) 2014. This article is published with open access at Springerlink.com

\begin{abstract}
Coal mine safety supervision system plays an important role in the coal mine safety management in China. However, the current supervision system is established on the basis of learning the advanced experience from other developed countries. It needs to be further improved according to national conditions. Therefore, the effectiveness of coal mine safety supervision system reform on three types of collieries are assessed by using time series analysis method based on comparative analysis of the supervision system before and after the reform in this paper. The regression results show that the structural reform is not conductive to the improvement of coal mine safety situation in the short term, but conductive significantly in the long term. Specifically, the effects in township coal mines are more significant than stateowned key coal mines in the long run, but negative effects also exist in the short term. The negative effects in state-owned key coal mines are non-significant compared with township coal mines. Moreover, the regression results are analyzed from the aspects of the closure policy of illegal small township coal mines at the end of 1998 and shortage of the new supervision system. Finally, the suggestions on improving the new supervision system are put forward based on the above analysis.
\end{abstract}

Keywords Coal mine safety supervision - Time series analysis - Structural reform - Death rate per million tonnes . Effectiveness of supervision

\section{Introduction}

Coal accounts for more than $70 \%$ of China's energy. The coal-dominated energy structure is unlikely to be changed for a long period because China is rich in coal, poor in oil and gas (Wang 2006). In recent years, frequent coal mine accidents not only caused huge losses of life and property, but also had a negative influence on the society. Although the data of total accidents, death toll and death rate per million tonnes from China Coal Industry Statistical

Q. Liu $(\bowtie) \cdot$ X. Li · F. Guan

School of Management, China University of Mining and

Technology, Xuzhou 221116, China

e-mail: liuquanlong1986@cumt.edu.cn
Yearbook have decreased year after year (Table 1), the coal mine safety situation is still very grim compared with some developed countries. Therefore, coal mine safety remains one of the most significant outstanding problems in China (Liu et al. 2011; Li 2012). The complex mining geological condition, backward technology and equipment, insufficient skills of miners, and weak safety foundation are the fact that does not dispute for the bad coal mine safety situation in China. But coal mine safety supervision system plays a dominant role in regulating collieries and bear great responsibility for China's bad coal mine safety situation. Consequently, China began to reform fundamentally the coal mine safety management system at the end of 1999 and established a new coal mine safety supervision system which is "State Supervision, Local Regulation and Enterprise Responsibility", namely the State Administration of Coal Mine Safety and the local coal mine safety regulation department share the task of administrative enforcement on 
Table 1 Safety situation after the coal mine safety supervision system reform in China

\begin{tabular}{|c|c|c|c|c|c|c|c|c|c|}
\hline \multirow[t]{2}{*}{ Time } & \multicolumn{3}{|c|}{ State-owned key coal mines } & \multicolumn{3}{|c|}{ Local state-owned coal mines } & \multicolumn{3}{|c|}{ Township coal mines } \\
\hline & $\begin{array}{l}\text { Output } \\
\text { (million } \\
\text { tonnes) }\end{array}$ & $\begin{array}{l}\text { Death } \\
\text { toll }\end{array}$ & $\begin{array}{l}\text { Death rate } \\
\text { per million } \\
\text { tonnes }(\%)\end{array}$ & $\begin{array}{l}\text { Output } \\
\text { (million } \\
\text { tonnes) }\end{array}$ & $\begin{array}{l}\text { Death } \\
\text { toll }\end{array}$ & $\begin{array}{l}\text { Death rate } \\
\text { per million } \\
\text { tones }(\%)\end{array}$ & $\begin{array}{l}\text { Output } \\
\text { (million } \\
\text { tonnes) }\end{array}$ & $\begin{array}{l}\text { Death } \\
\text { toll }\end{array}$ & $\begin{array}{l}\text { Death rate } \\
\text { per million } \\
\text { tones }(\%)\end{array}$ \\
\hline 1998 & 503.49 & 542 & 1.02 & 242.02 & 910 & 3.76 & 531.98 & 4,575 & 8.60 \\
\hline 1999 & 512.71 & 572 & 0.92 & 253.89 & 947 & 3.73 & 360.31 & 4,666 & 12.95 \\
\hline 2000 & 535.74 & 765 & 1.44 & 201.22 & 827 & 4.11 & 269.20 & 3,933 & 14.61 \\
\hline 2001 & 618.57 & 781 & 1.27 & 254.63 & 1,044 & 4.10 & 245.95 & 3,645 & 14.82 \\
\hline 2002 & 714.58 & 904 & 1.27 & 267.10 & 1,023 & 3.83 & 433.53 & 5,068 & 11.69 \\
\hline 2003 & 814.05 & 892 & 1.07 & 293.67 & 881 & 3.00 & 612.48 & 4,661 & 7.61 \\
\hline 2004 & 938.79 & 854 & 0.93 & 301.11 & 816 & 2.71 & 742.25 & 4,357 & 5.87 \\
\hline 2005 & $1,024.21$ & 984 & 0.93 & 279.41 & 570 & 2.04 & 792.77 & 4,384 & 5.53 \\
\hline 2006 & $1,119.56$ & 704 & 0.63 & 319.90 & 611 & 1.91 & 882.01 & 3,431 & 3.89 \\
\hline 2007 & $1,214.91$ & 475 & 0.38 & 318.60 & 411 & 1.29 & 960.26 & 2,900 & 3.02 \\
\hline 2008 & $1,377.81$ & 454 & 0.33 & 246.01 & 401 & 1.63 & 995.78 & 2,360 & 2.37 \\
\hline 2009 & $1,526.34$ & 580 & 0.38 & 394.25 & 294 & 0.75 & $1,091.92$ & 1,757 & 1.61 \\
\hline 2010 & $1,624.16$ & 478 & 0.29 & 519.73 & 255 & 0.49 & $1,199.72$ & 1,700 & 1.42 \\
\hline 2011 & $1,689.11$ & 351 & 0.21 & 549.16 & 231 & 0.42 & $1,259.96$ & 1,391 & 1.10 \\
\hline
\end{tabular}

coal mine safety production (Liu and Li 2013). But how was the effectiveness of the coal mine safety supervision system reform?

Many scholars at home and abroad studied the current problems of China's coal mine supervision system from different aspects to explain the high occurrence of coal mine accidents. Wright (2004) have analyzed the regulation of China's township and village collieries, they pointed out that the current regulatory policy can't solve the problem fundamentally and a targeted regulation system should be set up. A number of studies have quantitatively analyzed the effectiveness of coal mine safety supervisions (Viscusi 1979, 1986; Lewis-Back and Alford 1980; Gray and Jones 1991), and the results showed that there exist significant correlation between coal mine accidents rate and the intensity of government supervision. Chinese scholar Xiao $(2009,2010)$ have empirically studied the effectiveness of China's coal mine safety regulation based on VAR model, and he drew the conclusion that China's coal mine safety regulation was effective in the long run. However, there is less research on quantitative study of China's coal mine safety supervision, especially on quantitative study of the three types of collieries, and most research to date has focused on qualitative analysis. Therefore, in this paper, the effectiveness of coal mine safety supervision system reform on the three types of collieries (state-owned key coal mines, local state-owned coal mines and township coal mines) are studied by using time series analysis method.

\section{Materials and methods}

2.1 Comparative analysis of the supervision system before and after the reform

China's coal administrative supervision system and coal industry production system had been repeatedly changed with the characteristics of frequently separating and integrating in turn after long intervals (Yan 2009). Premier Zhou firstly put forward the policy of "safety first" in the first national coal conference in 1949 and then the Ministry of Fuel Industry was established which managed coal, electricity and oil industry. In 1953, the Technical Supervision Bureau was established which was subordinate to the Ministry of Fuel Industry, it marked the initial formation of coal mine safety management system, "administrative management, trade union supervision and labor department inspection". In July 1955, the Ministry of Coal Industry and its subordinate Safety Supervision Bureau were established by withdrawing the Ministry of Fuel Industry in the second session of the first National People's Congress. But coal mine safety supervision had not been paid enough attention in the actual coal production, especially in the period of "Great Leap Forward" and "Cultural Revolution", which was interrupted (Wang 2004). In short, the management system was the "almighty management mode" in this period.

After the Third Plenary Session of the 11th Central Committee, China's coal mine safety management entered a new stage of recovery and development, and gradually 
institutionalized, it showed a change from the "almighty management mode" to "supervision management mode". In 1983, the Ministry of Coal Industry promulgated the Regulations of Coal Mine Safety Supervision. In 1993, the State Council proposed the coal mine safety management system which is "enterprise responsibility, state supervision, sectional management and public surveillance" according to the development of the reform of market system and state-owned coal mining enterprises. In 1998, the organ of the State Council reformed, and the Ministry of Coal Industry was canceled and its coal mine safety work was allocated to the Safety Production Bureau of State Economic and Trade Commission.

China began to reform fundamentally the coal mine safety management system at the end of 1999. On December 30 1999, the General Office of the State Council of the People's Republic of China promulgated the "Circular on Printing and Distributing the Implementation Plan on the Reform of Coal Mine Safety Management System" and drafted the new Regulations of Coal Mine Safety Supervision, and began to establish a new coal mine safety supervision system which was vertical management (Zhang 2001). In 2001, the new coal mine safety supervision system was composed of 19 provincial administration of coal mine safety bureaus and 68 sub-administration of coal mine safety offices, which was three-level and vertical supervision system included the state, province and region levels. In March 2003, the State Administration of Work Safety (the State Administration of Coal Mine Safety) became the institutions directly under the State Council and was responsible for the comprehensive management of national safety production and coal mine safety supervision. In 2005, the State Administration of Work Safety was upgraded to a ministry-level agency, and the State Administration of Coal Mine Safety was set up separately and upgraded to a vice-ministerial level agency under the State Administration of Work Safety. In 2006, the general office of the State Council promulgated "Views on the Relevant Issues about Strengthening the Coal Industry Management" and transferred the functions related to coal mine safety from the State Development and Reform Commission to the State Administration of Coal Mine Safety. Since then, China's coal mine safety supervision was dual leadership of the State Administration of Coal Mine Safety and the local government, and mainly by the State Administration of Coal Mine Safety (Wang 2010), namely the State Administration of Coal Mine Safety and the local coal mine safety regulation departments share the task of administrative enforcement on coal mine safety production, as shown in Fig. 1.

\subsection{Model design and data}

The time series analysis method was used in assessing the effectiveness of many policies by many scholars, and it has improved continuously and has been proved to have strong explanatory power on assessing the effectiveness of structural reform (Zheng and Cui 2011). The basic idea of this method is that select a continuous period data which can reflect the safety situation and design the econometric model. Firstly, the econometric model was designed as follows according to the above comparative analysis of supervision system before and after the reform.

$Y_{t}=\beta_{0}+\beta_{1} X_{1 t}+\beta_{2} D_{1 t}+\beta_{3} D_{2 t}+e_{t}$

where $Y_{t}$ is the variable used to represent the annual safety situation of coal mines; $X_{1 t}$ is the time variable, also called the trend variable and used to assess the time, value from 1 to $\mathrm{N} ; D_{1 t}$ is the dummy variable, and given the value 0 before 2,000 and 1 after 2,$000 ; D_{2 t}$ is the dummy variable that assess the time, and given the value 0 before 2,000 and $1,2,3, \ldots$ after 2,$000 ; \beta_{0}, \beta_{1}, \beta_{2}$ and $\beta_{3}$ are the regression coefficient; and $e_{t}$ is the residuals.

In the above model, $\beta_{0}$ and $\beta_{1}$ represent the safety level of coal mine and variation trend respectively, namely the intercept and slope of linear regression. And $\beta_{2}$ and $\beta_{3}$ represent the effects after the structural reform in 2000 . Specifically, $\beta_{2}$ represents level effects, namely short-term effects; and $\beta_{3}$ represents trend effects, namely long-term effects. Therefore, the effectiveness of the structural reform can be obtained from assessing whether $\beta_{0}$ and $\beta_{1}$ are affected or not, namely detecting the statistical significance of $\beta_{2}$ and $\beta_{3}$. If $\beta_{2}$ is significantly different from 0 , then the supervision system reform has a short-term effects on the improvement of coal mine safety, and vice versa. And if $\beta_{3}$ is significantly different from 0 , then the supervision system reform has a long-term effects on the improvement of coal mine safety, and vice versa. Finally, the effectiveness of the supervision system reform on state-owned key coal mines, local state-owned coal mines and township coal mines can be obtained by using the above econometric model.

In the econometric model, the value of $X_{1 t}, D_{1 t}$ and $D_{2 t}$ have been given except $Y_{t}$. There are many indicators which can represent the annual safety situation of coal mines, such as the data of annual total accidents, death, et al. However, in this paper, we selected the death rate per million tonnes as the assessment indicator for the following considerations. Firstly, death is the most serious accident consequences in coal mine production. Secondly, the death rate per million tonnes has a high correlativity with other data and can reflect other data indirectly. Thirdly, it is more generic and not be affected by other factors, such as output of coal, death toll, et al.

The data of death rate per million tonnes in state-owned key coal mines, local state-owned coal mines and township coal mines are collected from China Coal Industry Statistical Yearbook and the website of State Administration of 


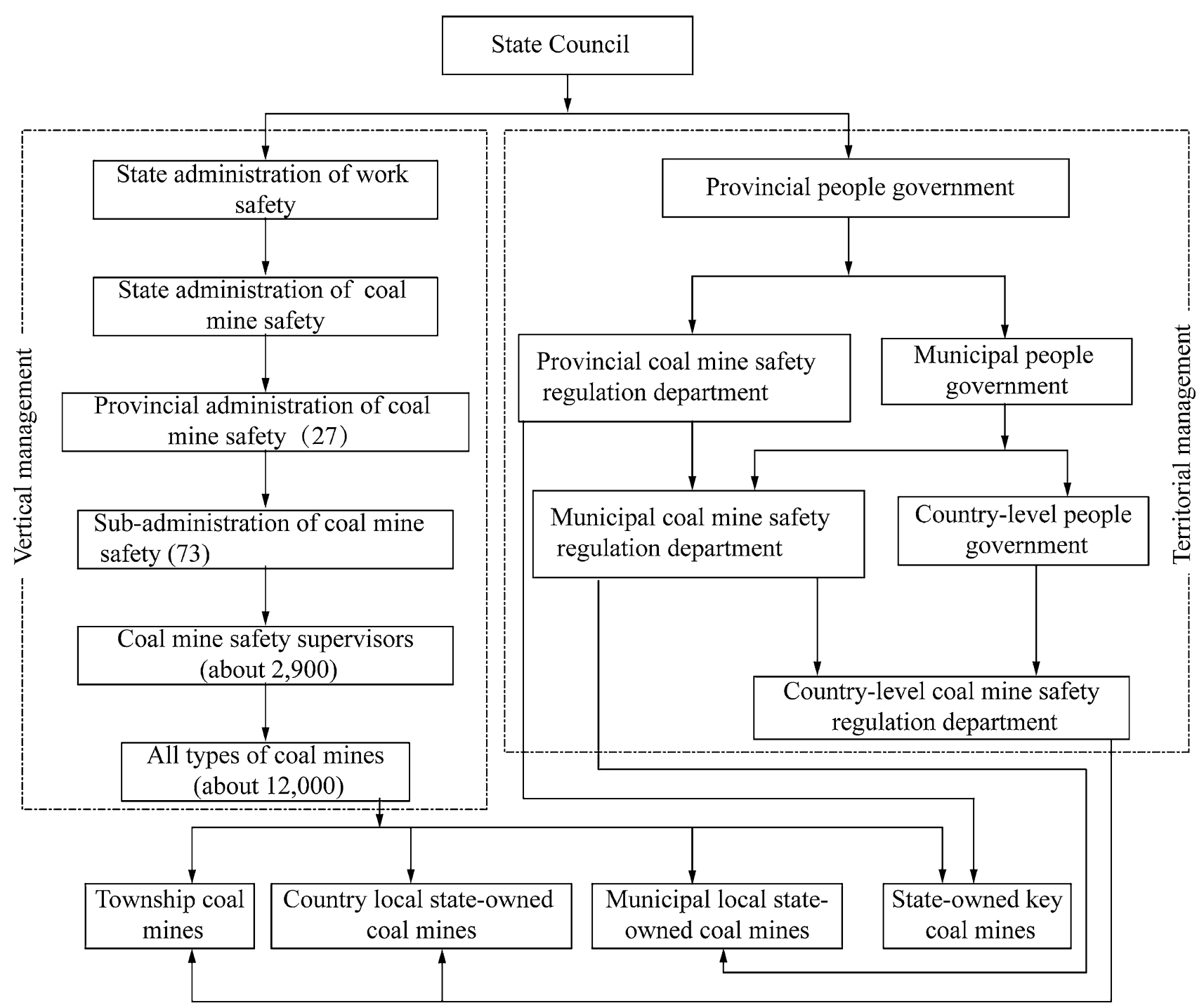

Fig. 1 Structure of coal mine safety supervisions system in China

Coal Mine Safety, and the sample interval is 1989-2011. The value of $X_{1 t}, D_{1 t}, D_{2 t}$, and $Y_{t}$ are shown in the following Table 2 based on the above analysis.

\subsection{Empirical results}

The regression coefficients of the econometric model are obtained by using the econometric analysis software EViews (Zheng and Cui 2011), and they are tested with F-test, $t$ test, Heteroskedasticity test and Autocorrelation test. Furthermore, the model is modified continually until it passed all the tests at the significance level of $5 \%$. Finally, the regression results of the model are sort out in Table 3.

The following results can be drawn from the Table 3 .

(1) The structural reform has had a big influence on the safety situation of coal mines and its work is effective on the whole. Specifically, the regression coefficients of $C, X_{1 t}, D_{1 t}$ and $D_{2 t}$ are all significant under the significance level of $5 \%$, and their symbols of t-stat are positive, negative, positive and negative respectively. And the results show that there are different degrees of improvement trend of safety situation in state-owned key coal mines, local state-owned coal mines and township coal mines.

(2) Coal mine safety situation in state-owned key coal mines is better than local state-owned coal mines, and local state-owned coal mines is better than township coal mines before the structural reform according to $\beta_{0}$ (state-owned key coal mines) $>\beta_{0}$ (local stateowned coal mines) $>\beta_{0}$ (township coal mines). This is correspond to actual situation that the state-owned key coal mines mostly have large production scale 
and high equipment and technology level while the township coal mines mostly have small production scale, less investment and backward equipment and technology.

(3) In the short term, the structural reform is not conductive to the improvement of coal mine safety situation, and negative effects are different in the three types of collieries. Specifically, the negative

Table 2 Data of $Y_{t}, X_{1 t}, D_{1 t}$, and $D_{2 t}$ in 1989-2011

\begin{tabular}{|c|c|c|c|c|c|c|}
\hline \multirow[t]{2}{*}{ Time } & \multicolumn{3}{|l|}{$Y_{t}$} & \multirow[t]{2}{*}{$X_{1 t}$} & \multirow[t]{2}{*}{$D_{1 t}$} & \multirow[t]{2}{*}{$D_{2}$} \\
\hline & $\begin{array}{l}\text { State-owned } \\
\text { key coal } \\
\text { mines }\end{array}$ & $\begin{array}{l}\text { Local state- } \\
\text { owned coal } \\
\text { mines }\end{array}$ & $\begin{array}{l}\text { Township } \\
\text { coal mines }\end{array}$ & & & \\
\hline 1989 & 1.74 & 6.30 & 13.00 & 1 & 0 & 0 \\
\hline 1990 & 1.43 & 5.00 & 12.79 & 2 & 0 & 0 \\
\hline 1991 & 1.06 & 6.20 & 10.10 & 3 & 0 & 0 \\
\hline 1992 & 1.01 & 4.50 & 9.20 & 4 & 0 & 0 \\
\hline 1993 & 1.12 & 4.90 & 8.50 & 5 & 0 & 0 \\
\hline 1994 & 1.19 & 4.82 & 8.32 & 6 & 0 & 0 \\
\hline 1995 & 1.16 & 4.90 & 8.13 & 7 & 0 & 0 \\
\hline 1996 & 1.17 & 4.02 & 7.70 & 8 & 0 & 0 \\
\hline 1997 & 1.45 & 4.13 & 8.44 & 9 & 0 & 0 \\
\hline 1998 & 1.02 & 3.76 & 8.60 & 10 & 0 & 0 \\
\hline 1999 & 0.92 & 3.73 & 12.95 & 11 & 0 & 0 \\
\hline 2000 & 1.44 & 4.11 & 14.61 & 12 & 1 & 1 \\
\hline 2001 & 1.27 & 4.10 & 14.82 & 13 & 1 & 2 \\
\hline 2002 & 1.27 & 3.83 & 11.69 & 14 & 1 & 3 \\
\hline 2003 & 1.07 & 3.00 & 7.61 & 15 & 1 & 4 \\
\hline 2004 & 0.93 & 2.71 & 5.87 & 16 & 1 & 5 \\
\hline 2005 & 0.93 & 2.04 & 5.53 & 17 & 1 & 6 \\
\hline 2006 & 0.63 & 1.91 & 3.89 & 18 & 1 & 7 \\
\hline 2007 & 0.38 & 1.29 & 3.02 & 19 & 1 & 8 \\
\hline 2008 & 0.33 & 1.63 & 2.37 & 20 & 1 & 9 \\
\hline 2009 & 0.38 & 0.75 & 1.61 & 21 & 1 & 10 \\
\hline 2010 & 0.29 & 0.49 & 1.42 & 22 & 1 & 11 \\
\hline 2011 & 0.21 & 0.42 & 1.10 & 23 & 1 & 12 \\
\hline
\end{tabular}

effects in state-owned key coal mines are nonsignificant compared with township coal mines.

(4) In the long term, the structural reform is conductive significantly to the improvement of coal mine safety situation, and positive effects are also different in the three types of collieries. Specifically, the effects of the new supervision system in township coal mines are more significant than the effects in state-owned key coal mines. Therefore, the township coal mines have much room for improvement compared with the state-owned coal mines.

\section{Results analyses}

The regression results are mainly analyzed from the aspects of the closure policy of illegal small township coal mines at the end of 1998 and shortage of the new supervision system.

3.1 The closure policy of illegal small township coal mines at the end of 1998

The structural reform is not conductive to the improvement of coal mine safety situation in the short term, and this result can also be shown in Table 1, which the death rate per million tonnes fluctuated greatly in 1998-2002, especially in the township coal mines. This result is much more related with the closure policy of illegal small township coal mines at the end of 1998.

The closure policy has mainly brought two aspects of negative influence. Firstly, the closure of small coal mines was carried out in batches, so when a number of small coal mines was closed, other small coal mines would have a sense of crisis and then they would produce hastily and didn't pay attention to safety issues more before they were shut down, which lead to the increase of accidents. Secondly, the supply of coal decreased greatly and may

Table 3 Regression results

\begin{tabular}{|c|c|c|c|c|c|c|c|c|c|}
\hline \multirow[t]{2}{*}{ Explanatory variables } & \multicolumn{3}{|c|}{ State-owned key coal mines } & \multicolumn{3}{|c|}{ Local state-owned coal mines } & \multicolumn{3}{|c|}{ Township coal mines } \\
\hline & Coefficient & $t$-stat & $P$-stat & Coefficient & $t$-stat & $P$-stat & Coefficient & $t$-stat & $P$-stat \\
\hline$C\left(\beta_{0}\right)$ & 1.436 & 13.236 & 0.0000 & 6.113 & 25.280 & 0.0000 & 11.177 & 9.109 & 0.0000 \\
\hline$X_{1 t}$ & -0.038 & -2.393 & 0.0278 & -0.227 & -6.369 & 0.0000 & -0.231 & -1.274 & 0.0218 \\
\hline$D_{1 t}$ & 0.549 & 3.815 & 0.0013 & 1.044 & 3.253 & 0.0044 & 6.037 & 3.811 & 0.0012 \\
\hline$D_{2 t}$ & -0.087 & -3.858 & 0.0012 & -0.157 & -3.126 & 0.0058 & -1.085 & -4.508 & 0.0002 \\
\hline$R^{2}$ & 0.845 & & & 0.955 & & & 0.828 & & \\
\hline$F$-stat & 32.63 & & & 127.84 & & & 30.58 & & \\
\hline$D-W$ test & 1.91 & & & 2.14 & & & 1.82 & & \\
\hline
\end{tabular}


even in short supply owning to closing many small coal mines, which would lead to high coal prices and profits and then many other coal mines would be possible to increase their outputs and ignore the safety issues. Many illegal small township coal mines couldn't be completely shut down. Some of them still recovered production behind closed doors, and they produced hastily and didn't pay attention to safety issues more for compensating the considerable loss in their rectification period. In short, the negative effects from the closure period and recovery period greatly lead to the safety record worsened in the short term.

3.2 The shortage of the new coal mine safety supervision system

The regression results show that the structural reform is conductive significantly to the improvement of China's coal mine safety situation in the long run and its effect is significant at the significance level of $5 \%$, but the goodness of fit of the data are not very good. From the aspect of the shortages of the new coal mine safety supervision system, the reasons are as follows.

(1) The vertical supervision system has caused unclear rights and responsibilities between the State Administration of Coal Mine Safety and the local coal mine regulation departments. Because of lacking effective coordination mechanisms, the two kinds of department act of their own free will for their interests, and even some central supervision departments and local regulation departments are the one department in some areas and they undertake the function of supervision and management at the same time (Zhen 2009).

(2) The Administration of Coal Mine Safety is short of independence and authority. In the process of law enforcement, they have no independent power of penalty and compulsory right to execution on local regulation departments' illegal enforcement or coal mines' illegal production (Xiao 2010).

(3) The local coal mine safety regulation departments are of serious malpractice on regulating their territorial mines. The local government has great law enforcements in the coal mine safety supervision and regulation work, but in order to develop its local economy, it often ignore national interests and longterm interests and cause the prevalence of local protectionism.

In short, the above shortages of the new coal mine safety supervision system have weakened its supervision effects, and this also increased the probability of accidents to a large extent.

\section{Conclusions and suggestions}

In this paper, we studied the effectiveness of coal mine safety supervision system reform on state-owned key coal mines, local state-owned coal mines and township coal mines by using time series analysis method. The regression results show that the structural reform has had a big influence on the safety situation of coal mines and its work is effective on the whole. In the short term, the structural reform is not conductive to the improvement of coal mine safety situation, and negative effects are different in the three types of coal mines. Specifically, the negative effects in state-owned key coal mines are non-significant compared with township coal mines. In the long term, the structural reform is conductive significantly to the improvement of coal mine safety situation, and positive effects are also different in the three types of coal mines. Specifically, the effects of the new supervision system in township coal mines are more significant than the effects in state-owned key coal mines. Therefore, the Administration of Coal Mine Safety should take measures to perfect its supervision system on the basis of the above conclusions and analysis. (1) Ensure the independence and authority of the Administration of Coal Mine Safety, and establish effective supervision system to avoid its abuse of power at the same time; (2) avoid frequent changes of supervision organization and coordinate its relationship with the legislation departments, administration departments and justice department; (3) stabilize the policy on the township coal mines and encourage long-term legal business, and also periodically inspect the township coal mines which have passed the security acceptance; (4) weaken the beneficial relations between local government and township coal mines. The tax from the township coal mines can be mostly submitted to central government and then return to local government according to their different demands, and the rest can be used as safety fund for granting appropriate subsidies to the legitimate township coal mines.

Acknowledgments This work was supported by the National Natural Science Foundation Projects of China under Grant 71271206; and Innovation Project of Graduate Education for Jiangsu Province under Grant KYZZ_0377.

Open Access This article is distributed under the terms of the Creative Commons Attribution License which permits any use, distribution, and reproduction in any medium, provided the original author(s) and the source are credited.

\section{References}

Gray WB, Jones CA (1991) Are OASA health inspections effective? a longitudinal study in the manufacturing sector. Rev Econ Stat 73(3):504-508 
Lewis-Back MS, Alford JR (1980) Can government regulate safety? The coal mine example. Am Polit Sci Rev 74(3):745-756

Li JK (2012) China strategic coal stockpile and its supervision mechanism. Economy \& Management Publishing House, Beijing

Liu QL, Li XC (2013) Study on the efficiency of the structural reform of coal mine safety supervision system in China. China Popul Resour Environ 23(11):161-167

Liu QL, Li XC, Zhang QC (2011) Study on the risk measurement and the coupling analysis of multi hazard source in coal gas accident. J Saf Coal Mines 42(7):189-192

Viscusi WK (1979) The impact of occupational safety and health supervision. Bell J Econ 10(1):117-140

Viscusi WK (1986) The impact of occupational safety and health supervision in 1973-1983. Rand J Econ 17(4):567-580

Wang SG (2004) The regulation of coal mine safety production: the transformation of China's governance mode. Comp Stud $13: 79-110$

Wang MZ (2006) Innovate the safety supervision and constructing the harmonious society. Mod Occup Saf 12:62-64
Wang BJ (2010) Safety management of modern coal mine production in China. China Sci Technol Rev 06:190-190

Wright $\mathrm{T}$ (2004) The political economy of coal mine disasters in China: your rice bowl or your life. China Q 179:629-646

Xiao XZ (2009) The economic analysis of coal mine safety supervision in China. Capital University of Economics and Business Press, Beijing

Xiao XZ (2010) Theory and practice of coal mine safety supervision in China. Science press, Beijing

Yan Y (2009) The changes in China's coal mine safety supervision system. Contemp China Hist Stud 16:42-51

Zhang YJ (2001) Analysis of the township coal mine safety supervision system. China Coal 27(10):48-50

Zhen Y (2009) Reflection on China's coal mine safety production supervision. J Shandong Inst Bus Technol 23(04):31-34

Zheng FT, Cui HX (2011) Economic analysis of safety supervision. Huazhong University of Science and Technology Press, Wuhan 